\title{
TINJAUAN HUKUM ISLAM TERHADAP WALIMATUL 'URSY DI RUMAH GADANG (Studi di Nagari Abai Kecamatan Sangir Batang Hari)
}

\author{
Hengki Saputra1, Nailur Rahmi ${ }^{2}$ \\ ${ }^{1}$ Institut Agama Islam Negeri (IAIN) Batusangkar \\ e-mail: hengkisaputra403@gmail.com \\ 2 Institut Agama Islam Negeri (IAIN) Batusangkar \\ e-mail: nailurrahmi@iainbatusangkar.ac.id
}

\begin{abstract}
This study examines walimatul ursy. The problem is the walimatul 'ursy in the gadang house in Nagari Abai, Sangir Batang Hari District, South Solok Regency. From these problems the question arises how the process of implementing the walimatul'ursy tradition at the gadang house in Nagari Abai, Sangir Batang Hari District, South Solok Regency. This research is a field research (Field Research). Data obtained through interviews and documentation. Furthermore, the data is narrated descriptively. The results are discussed with the proposed theories. This study found that walimatul 'ursy in the rumah gadang is a tradition carried out with the terms and conditions that have been applied and to carry out it must obtain permission from the datuak. who leads the tribe and from the Datuak Fourteen. Meanwhile, according to Islamic law, the tradition of doing walimatul'ursy at the rumah gadang is categorized as something good which is a symbol of the condition of the bride and groom and the bride's family, so it can be classified as maslabah.
\end{abstract}

Keywords: Islamic Law, Walimatul Ursy, Rumah Gadang

\section{PENDAHULUAN}

A gama Islam menetapkan bahwa untuk membangun rumah tangga dan keluarga yang damai dan teratur haruslah dengan perkawinan dan akad nikah yang sah, dengan diketahui dan disaksikan sekurang-kurangnya dua orang saksi, sehingga dianjurkan untuk diumumkan kepada tetangga dan karib kerabat dengan mengadakan "walimatul "ursy". (Ramulyo, 1999: 31-32). Cara melaksanakan walimah dalam Islam tidak dijelaskan secara eksplisit. Hal ini dapat diartikan bahwa mengadakan walimah itu bentuknya bebas, asal tidak bertentangan dengan prinsip ajaran agama, dan juga tergantung adat istiadat masyarakatnya. Hal terpenting dalam melaksanakan walimah itu disesuaikan dengan kemampuan dan tidak sampai terjadi pemborosan atau mubazir, serta tidak ada maksudmaksud lain yang dilarang agama seperti membanggakan diri, memamerkan kekayaan (riya) dan hal-hal lain yang bertentangan dengan agama.

Walimah atau pesta pernikahan di setiap wilayah di Indonesia dilaksanakan dengan proses yang berbeda-beda berdasarkan adat dan kebiasaan dari masing-masing wilayah di Indonesia (Putri, 2021). Pelaksanaan adat dan kebiasaan sesuai dengan nilai dan norma yang dianut di dalam masyarakat (Putri, 2021). Tidak hanya pada pesta pernikahan, upacara kematian pun dilaksanakan secara berbeda antar satu daerah dengan daerah yang lain (Putri, 2021). Salah satu contohnya adalah pelaksanaan pesta pernikahan diNagari Abai Kecamatan Sangir Batang Hari Kabupaten Solok Selatan. Dari obeservasi awal diperoleh informasi bahwa setelah terjadinya akad dalam sebuah pernikahan maka setelahnya akan diadakan pesta pernikahan. Pesta tersebut dilaksanakan selama tujuh hari tujuh malam, hampir semua pasangan yang telah melaksanakan pernikahan akan merayakan walimah dengan adat kebiasaan yang terjadi di kampung tersebut. Namun 
efektifitas pelaksanaan prosesi walimatul ursy di rumah gadang dalam pandangan hukum Islam mengenai acara adat tersebut, tetapi jika melaksanakan walimatul 'ursy tersebut di rumah pasangan Marapulai maka akan mendapatkan sanksi sosial seperti dipergunjingkan, tidak dilibatkan dalam acara adat. Apakah dalam hukum Islam ada ketetentuan yang mengharuskan dan juga melarang walimatul 'ursy di rumah gadang. Berdasarkan fenomena yang ada, maka akan dikaji lebih dalam tentang bagaimana prosesi adat walimatul 'ursy di rumah gadang dan pandangan hukum Islam terhadap hal tersebut.

\section{METODE PENELITIAN}

Penelitian ini adalah penelitian lapangan (Field Research). Data diperoleh melalui wawancara dan dokumentasi. Setelah data terkumpul diolah dengan cara triangulasi. Selanjutnya data dinarasikan secara deskriptif sehingga dapat menjawab permasalahan yang diteliti.

\section{HASIL DAN PEMBAHASAN}

\section{A. Prosesi Tradisi Walimatul 'Ursy di Rumah Gadang di Nagari Abai Kecamatan Sangir Batang Hari Kabupaten Solok Selatan}

Sejarah awal walimatul 'ursy di Rumah Gadang terjadi pada zaman dahulu yaitu banyak masyarakat di Kenagarian Abai menetap di rumah gadang dengan hidup rukun dengan banyak kepala keluarga dalam satu kamar di Rumah Gadang tersebut, pada zaman tersebut rumah gadang bukanlah hanya sebagai tempat untuk baralek saja namun juga untuk tempat beristirahat bagi masyarakat pada masa lalu. Namun seiring dengan berjalan waktu rumah gadang beralih fungsi sebagai tempat untuk merayakan hal yang bersangkutan dengan adat, seperti upacara adat, upacara pernikahan dan segala sesuatu yang berkaitan dengan adat. Walimatul 'ursy dari zaman dahulu sampai zaman sekarang prosesnya masih dilaksanakan seperti seperti dahulu, namun seiring dengan agama islam sebagai agama yang mayoritas di Minangkabau maka hal-hal yang bertentangan dengan agama Islam perlahan-lahan mulai di hilangkan dalam kegiatan upacara adat, maupun upacara pernikahan di minang kabau, walimatul ursy di rumah gadang merupakan suatu kebiasaan yang dilakukan oleh masyarakat kenagarian Abai yang masih digemari oleh masyarakat setempat hingga saat sekarang ini.

Walimatul 'ursy di rumah gadang merupakan suatu tradisi yamg telah ada sehingga diteruskan hingga saat sekarang ini, sehingga dapat dikatakan bahwa suatu tradisi yang memang sudah ada sehingga rumah gadang yang ada tidak hancur begitu saja. Di kumpulkannya Tunganai yang inti-inti di rumah gadang tersebut setelah itu dipanggil Datuak yang bersangkutan setelah itu melakukan perkumpulan di rumah gadang untuk mengambil keputusan, kapan akan dilaksanakannya walimatul 'ursy dan apa yang akan kita sembelih. (wawancara: Datuak Sari Baso, 22 Februari 2021).

Walimatul 'ursy di rumah gadang disini adalah suatu tempat yang dijadikan sebagai tempat baralek/tempat untuk merayakan sebuah pernikahan yang dilaksanakan di Nagari Abai sebagai bentuk kekerabatan dalam nagari tersebut yang telah ada yang harus di jaga agar rumah gadang sebagai simbol dari MinangKabau tidak punah sehingga bisa 
dinikmati oleh anak kemenakan untuk masa yang akan mendatang (Putri, 2020). Baralek di rumah gadang merupakan suatu tempat dimana perkumpulan Datuak dan Tungganai, Alim Ulama, Niniak Mamak, Andeh Bapak, Bundo Kanduang, dan anak kemenakan untuk dipertemukan sebelum melaksanakan baralek di rumah gadang tersebut, dan juga untuk mengetahui sanak family yang jauh atau belum saling mengenal karena jarak, maka di rumah gadang bisa saling mengenal supaya tidak ada yang tidak tahu dengan dunsanak atau dengan kerabat yang dekat dengan mereka maka disitu kesempatan untuk saling mengenal, baralek di rumah gadang sebelum dilaksanakan banyak proses yang harus di tempuh terlebih dahulu supaya ada takaran dalam melaksanakannya apakah baralek tujuh hari tujuh malam, atau hanya sekedar berdoa berdasarkan kemampuan bagi keluarga yang melaksanakan walimatul 'ursy di rumah gadang.

Kemudian saat berlangsungnya walimatul 'ursy di rumah gadang yang dilaksanakan oleh pihak keluarga Marapulai, maka keluarga marapulai harus menyampaikan kepada masyarakat dengan memberitahukan bahwa mereka sedang melaksanakan baralek di rumah gadang agar tidak ada yang mengetahui secara mendadak dan tidak diketahui oleh orang satu nagari dan juga agar dihindari dari fitnah bahwa mereka telah melaksanakan walimatul 'ursy di rumah gadang, walimatul 'ursy di rumah gadang juga sebagai tempat oleh muda dan mudi untuk menampilkan karya seni seperti silat, batombe, tari, dan bermain alat musik sebagai suatu tradisi dan karya melalui baralek di rumah gadang inilah merupakan kesempatan untuk melihatkan aksi tersebut. (wawancara: Datuak Sari Baso, 22 Februari 2021).

Setiap walimah yang memakai adat di Nagari Abai harus dilaksanakan di rumah gadang tetapi makna di haruskan walimatul 'ursy di rumah gadang adalah untuk keluarga marapulai yang menyembelih sapi sebagai hidangan untuk menghidang Datuak Ampek Baleh atau untuk menampung pemimpin adat, kepala suku, kepala pemerintahan yang berada Nagari Abai sebagai adat yang telah ada dan dijalankan sebagaimana mestinya adat itu dijalankan dan juga agar bisa dilaksanakan walimatul ursy tujuh malam dengan mengadakan kesenian batombe sebagai tradisi berbalas pantun yang merupakan sebagai suatu kegembiraan oleh masyarakat Nagari Abai bisa melaksanakan walimatul 'ursy di rumah gadang, tetapi jika walimatul 'ursy tersebut hanya menyembelih ayam atau kambing tidak harus mengundang dan menghidangkan Datuak Ampek Baleh, pemuka adat dan pemerintahan, maka walimatul ursy tersebut tidak harus dilaksanakan di rumah gadang. (wawancara: Kadirun, 24 Februari 2021).

Hal yang perlu dipersiapkan sebelum hendak melaksanakan walimatul 'ursy di rumah gadang adalah:

a. Kayu api yang digunakan memasak segala bentuk hidangan yang akan dibuat pada walimatul 'ursy di rumah gadang

b. Memberitahukan kepada tungganai di rumah gadang bahwa kita akan melaksanakan pesta pernikahan di rumah gadang tersebut

c. Menyiapkan satu ekor sapi atau satu ekor berdua berdasarkan kesepakatan kedua kelauarga yang akan melaksanakan walimatul ursy di rumah gadang

d. Mengumpulkan inyiak bapak yaitu untuk memberitahukan kepada laki-laki yang telah menikah dipersukuan tersebut, untuk saling membantu dan mengumpulkan 
uang untuk membantu keluarga yang akan melaksanakan walimatul ursy di rumah gadang

e. Mengumpulkan inyiak mamak untuk memberitahukan apa saja yang di butuhkan untuk melaksanakan walimatul 'ursy di rumah gadang tersebut, dan juga mengumpulkan uang disaat perkumpulan di rumah keluarga yang akan melaksanakan walimatul ursy di rumah gadang (wawancara: Datuak Penghulu Sati, 22 Februari 2021)

Prosesi Tradisi walimatul 'ursy di rumah gadang di Nagari Abai kecamatan Sangir Batang Hari Kabupaten Solok Selatan sebagai berikut:

a. Meminang atau khitbah

Sebagaimana mestinya seorang laki-laki yang hendak melakukan peminangan kepada perempuan, maka pihak laki-laki harus mendatangi pihak keluarga perempuan terlebih dahulu dengan membawa bapak dan ibu maupun keluarga yang dekat dengan laki-laki, dan menyatakan dalam pertemuan tersebut, bahwa pihak laki-laki ingin menyampaikan niat baiknya untuk meminang wanita tersebut untuk dijadikan isterinya. (Wawancara dengan ibu Epi Elisanti selaku masyarakat yang pernah melaksanakan walimatul 'ursy di rumah gadang pada tahun 2018, 26 Februari 2021)

b. Rapat musyawarah kedua keluarga

Rapat yang dilakukan oleh pihak keluarga masing-masing yang akan melaksanakan walimatul 'ursy merupakan suatu langkah yang biasanya dilakukan oleh para keluarga yang akan melaksanakan walimatul ursy di rumah gadang apakah akan melaksanakan walimatul dengan menyembelih sapi satu ekor perorangan atau satu ekor berdua yang merupakan syarat untuk melaksanakan walimatul 'ursy di rumah gadang yang harus disepakati sebelum walimatul 'ursy itu dilaksanakan, dan nantinya akan disepakati pula kapan waktu walimah itu akan dilaksanakan berdasarkan kesepakatan kedua belah pihak berdasarkan kemampuan dari masing-masing yang akan melaksanakan walimah 'ursy di rumah gadang. (Wawancara dengan ibu Nora Yuneri Astuti selaku masyarakat yang pernah melaksankan walimatul 'ursy di rumah gadang pada tahun 2018)

c. Walimatul di rumah gadang

Setelah melaksanakan akad nikah tidak lama setelah akad dan berdasarkan kesepakatan yang telah dibuat dan disepakati maka selanjutnya akan dilaksanakan walimatul 'ursy atau pesta pernikahan boleh dilaksanakan setelah selesainya akad nikah satu minggu atau beberapa bulan atau berdasarkan kesepakatan yang telah disepakati.

Ketika melaksanakan walimatul 'ursy di rumah gadang keluarga yang akan melaksanakan walimah atau pesta pernikahan, walimatul 'ursy di rumah gadang dilaksanakan selama tujuh hari tujuh malam di rumah gadang, dimana keluarga yang akan melaksanakan walimatul ursy di rumah gadang dan juga telah menyepakati segala syarat yang telah ditentukan berdasarkan adat yang berlaku di nagari Abai maka walimah atau pesta pernikahan bisa dilakukan di rumah gadang. (Wawancara dengan bapak Ifriadi Siswanto selaku masyarakat yang pernah melaksankan walimatul 'ursy di rumah gadang pada tahun 2018, 20 Februari 2021). "Yang berfungsi didalam merayakan pesta pernikahan di rumah gadang ialah Niniak Mamak, Alim Ulama, Cadiak Pandai, Suluh Bendang dalam nagari, dan Tungganai-Tungganai, Bundo Kanduang, raja yang sedang 
berdaulat beserta pemerintahan dalam nagari itulah yang terlibat di dalam peralatan pesta pernikahan di rumah rumah gadang".

Berikut adalah proses walimatul 'ursy di rumah gadang yang dilakukan berdasarkan adat istiadat yang berlaku di Nagari Abai:

Hari pertama yaitu dilaksanakan pada hari Jum'at. Acara yang dilakukan pada hari pertama adalah manoang tando yaitu memperlihatkan cincin tunangan kepada mamak persukuan agar mamak persukuan mengetahui siapa keponakan yang akan melaksanakan walimatul 'ursy di rumah gadang tersebut, acara berikutnya yang di lakukan Mengundang Datuak Empat Belas dengan carano dan sirih oleh pihak perempuan yang mana di lakukan untuk melanjutkan proses akan di berlangsungkan walimatul 'ursy di rumah gadang supaya diketahui oleh pemuka adat yang ada dilingkungan adat yang berada di Nagari Abai, acara berikutnya yaitu menghiasi rumah gadang yang dilakukan pada malam harinya oleh kaum persukuan tersebut dimana acara menghiasi dihadiri oleh pihak keluarga dan kerabat yang dekat dengan Marapulai supaya rumah gadang dihiasi dengan indah dan nyaman untuk melangsungkan sebuah pesta pernikahan.

Hari kedua yaitu dilaksanakan pada hari Senin. Acara yang dilakukan adalah batombe yaitu kegiatan berbalas pantun oleh para pemuda dan pemudi untuk menghibur niniak mamak yang hadir dan semua kalangan masyarakat yang hadir untuk menyaksikan suatu tradisi yang khas dan supaya diketahui oleh anak-anak muda yang hadir di pesta pernikahan dimana batombe tersebut merupakan suatu tradisi yang berasal di Nagari Abai.

Hari ketiga dilaksanakan pada hari Selasa. Acara yang dilakukan batombe yang dihadiri oleh Mamak persukuan, atau pada hari tersebut dihadiri oleh Datuak yang berdaulat tinggi di persukuan tersebut, dengan membuat makanan dan minuman untuk begadang, dan banyak seni tradisional yang dilakukan pada hari kedua seperti rabab yang dilakukan untuk mengiringi batombe agar lebih indah supaya semua kalangan yang hadir terhibur.

Hari keempat dilaksanakan pada hari Rabu. Acara yang dilakukan pada hari Rabu adalah menyembelih sapi atau kerbau, sebagai syarat untuk melaksanakan walimah tujuh hari tujuh malam di rumah gadang.

Hari kelima dilaksanakan pada hari Kamis. Acara yang dilakukan pada adalah acara masak memasak oleh induak-induak persukuan dan oleh Sumando membawa mangkuk yang berisi makanan pokok oleh masyarakat sekampung, acara berikutnya menghidangkan makanan untuk tamu undangan.

Hari keenam dilaksanakan pada hari Jum'at. Acara yang dilakukan pada hari tersebut adalah pagi harinya makan dan minum Niniak Mamak dan Ande Bapak sepersukuan, acara berikutnya Setelah sholat Jum'at makan ba adat yang dihadiri oleh Datuak Empat Belas, Niniak Mamak, Bundo Kanduang, Alim Ulama, Cadiak Pandai, dan Ande Bapak. Ini adalah jamuan terakhir selama walimatul 'ursy untuk pemuka adat, pemuka agama dan masyarakat yang diberitahu untuk menghadiri pesta pernikahan tersebut. Acara berikutnya malam harinya laki-laki atau Marapulai tidur di rumah gadang perempuan dengan membawa teman laki-laki, dimana dalam acara tersebut akan menjadi 
sebuah pendekatan pihak laki-laki kepada pihak perempuan dan merupakan kesempatan untuk memperkenalkan dirinya kepada masyarakat dipersukuan tersebut.

Hari ketujuh dilaksanakan pada Sabtu. Acara yang dilakukan pada hari tersebut adalah sore harinya pai manyalang merupakan membawa singgang ayam kerumah gadang laki-laki, Setelah itu membagi kado yang ditukar dengan singgang ayam atau sambal ayam. (wawancara: Kadirun, Rabu, 24 Februari 2021)

Tradisi walimatul 'ursy di rumah gadang ini bahwa menurut pandangannya sejauh tradisi itu tidak mengganggu tatanan kehidupan masyarakat boleh-boleh saja dilakukan. Tapi seandainya sudah menjadi beban bagi masyarakat tersebut sebaiknya tradisi adat seperti ini harus di perbaiki atau ditinggalkan. Bagi masyarakat dan adat Minangkabau, budi bahasa (yang dimanifestasikan dalam bentuk raso, pareso, malu, dan sopan) merupakan suatu hal yang harus selalu dipelihara dan dipertinggi karena merupakan dasar dalam bersosialisasi. Kalau seseorang tidak berbudi bahasa, maka yang akan mendapat malu bukan saja orang yang bersangkutan, melainkan seluruh kaum kerabatnya. Hal ini lebih dikenal dengan perasaan sahino-samalu (sehina semalu). Oleh seb ab itu, budi bahasa merupakan wadah bagi masyarakat Minangkabau untuk diterima di lingkungannya. (Erizal Gani, 2009: 5).

\section{B. Tinjauan Hukum Islam Terhadap Prosesi Walimatul 'Ursy Di Rumah Gadang Di Nagari Abai Kecamatan Sangir Batang Hari Kabupaten Solok Selatan}

Allah SWT menurunkan syari'at (hukum) Islam untuk mengatur kehidupan manusia, baik selaku pribadi maupun selaku anggota masyarakat. Hukum Islam melarang perbuatan yang pada dasarnya merusak kehidupan manusia, sekalipun perbuatan itu disenangi oleh manusia atau sekalipun umpamanya perbuatan itu dilakukan hanya oleh seseorang tanpa merugikan orang lain, seperti seseorang minumminuman yang memabukkan (khamar). Dengan demikian Islam adalah agama yang memberi pedoman hidup kepada manusia secara menyeluruh, meliputi segala aspek kehidupannya menuju tercapainya kebahagiaan hidup rohani dan jasmani, baik dalam kehidupan individunya, maupun dalam kehidupan masyarakatnya. (Suparman Usman, 2001: 65-66).

Hukum Islam merupakan syari'at yang ditentukan oleh Allah SWT kepada Nabi Muhammad SAW yang mengatur tentang hubungan manusia dengan Allah dan hubungan manusia dengan manusia. Di antara hubungan sesama manusia yaitu mengenai perkawinan, yang menjadi dasar perkawinan tersebut Allah menjadikan manusia hidup berpasang-pasangan.

Berdasarkan hasil wawancara yang penulis dapatkan bahwasanya masyarakat di Nagari Abai kecamatan Sangir Batang Hari kabupaten Solok Selatan melaksanakan pesta pernikahan di rumah gadang sebagai tempat berlangsungnya pesta pernikahan bagi para keluarga yang telah melakukan akad pernikahan.

Maksud dari walimatul 'ursy di rumah gadang di Nagari Abai kecamatan Sangir Batang Hari kabupaten Solok Selatan merupakan suatu aturan atau tradisi dalam melakukan pesta pernikahan yang mana rumah gadang sebagai tempat untuk melangsungkan pesta pernikahan dengan syarat dan ketentuan yang telah dibuat berdasarkan kebiasaan yang telah berlangsung di Nagari Abai. Setelah melaksanakan 
akad pernikahan kedua belah pihak merayakan pesta pernikahan sebagai bentuk rasa dan syukur kedua pihak keluarga yang akan melakukan pesta pernikahan di Nagari Abai.

Dalam masyarakat Nagari Abai walimatul 'ursy di rumah gadang yang harus dilakukan setiap melaksanakan pesta pernikahan, walimah di rumah gadang merupakan suatu tradisi yang telah dilakukan sejak zaman nenek moyang sampai sekarang masih dilakukan oleh masyarakat Nagari Abai kecamatan Sangir Batang Hari kabupaten Solok Selatan.

Walimatul 'ursy di rumah gadang memiliki banyak manfaat seperti biasa menjadi sebuah isyarat doa untuk melangsungkan kehidupan rumah tangga, membantu ekonomi pengantin yang melakukan walimatul 'ursy di rumah gadang, dan juga memberi tahu kepada Datuak yang berdaulat tinggi yaitu Datuak Empat Belas sebagai kepala adat nagari dan lembaga kemasyarakatan yang ada di Nagari Abai, terkhususnya kepada masyarakat bahwasanya mempelai perempuan masih perawan atau gadis sebagaimana salah satu syarat untuk melakukan walimatul di rumah gadang di Nagari Abai kecamatan Sangir Batang Hari kabupaten Solok Selatan.

Tradisi melakukan pesta pernikahan di rumah gadang jika terjadi pelanggaran atau ada masyarakat di nagari Abai yang tidak melakukan pesta pernikahan di rumah gadang, maka masyarakat tersebut akan dipergunjingkan atau tidak diikut sertakan dalam kegiatan adat di Nagari Abai kecamatan Sangir Batang Hari kabupaten Solok Selatan. Sebagaimana yang penulis paparkan diatas melaksanakan walimatul 'ursy di rumah gadang di Nagari Abai kecamatan Sangir Batang Hari kabupaten Solok Selatan. Menurut penulis tradisi yang dilakukan merupakan suatu tradisi yang baik dan juga mendatangkan manfaat bagi kedua pihak keluarga yang melaksanakan walimatul 'ursy di rumah gadang dan juga biaya yang di keluarkan tidak terlalu banyak karena dibantu oleh masyarakat satu kampung maupun kerabat kedua belah pihak mempelai yang melakukan tradisi pesta pernikahan di rumah gadang, serta tradisi walimatul 'ursy di rumah gadang tidak menyulitkan kedua belah pihak baik pihak laki-laki maupun pihak perempuan.

Tujuan dari pelaksanaan walimatul 'ursy di rumah gadang ini untuk meraih sesuatu yang mengandung kebaikan dan mencegah keburukan. Dengan syarat tidak bertentangan dengan ketentuan syara'. Hadist yang mengatakan bahwa sebuah hukum yang dibuat tidak boleh bertentangan dengan hukum syara' yaitu sebagaimana hadist riwayat Bukhari dan Muslim.

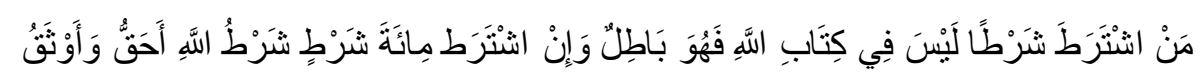

“Siapa yang membuat syarat yang tidak ada pada Ktab Allah maka merupakan syarat yang batal sekalipun dia membuat seratus syarat. Karena syarat yang dibuat Allah lebih hak dan lebih kokoh". (H.R. Bukhari No. 2010)

Hadist diatas dapat penulis pahami bahwa suatu syarat yang dibuat bertentangan dengan ketentuan syara' maka syara' tersebut batal, jika syara' tersebut dibuat sejalan dengan ketentuan syara' maka syara' tersebut sah dan dapat diikuti, sedangkan pelaksanaan tradisi walimatul 'ursy di rumah gadang dilakukan oleh mempelai dalam walimah di rumah gadang mempelai perempuan maupun rumah gadang laki-laki, aturan adat telah dirancang oleh orang terdahulu dengan sebaik mungkin terkhususnya tradisi 
walimatul 'ursy di rumah gadang dan juga banyak mempunyai makna tersirat didalamnya.

Berdasarkan analisa penulis pelaksanaan tradisi walimatul 'ursy di rumah gadang di nagari Abai kecamatan Sangir Batang Hari kabupaten Solok Selatan menurut pandangan hukum islam pada dasarnya adalah masuk kepada kategori yang baik meskipun tidak diperintah secara tegas, kategori yang seperti itu masuk kepada maslahah. Karena tradisi walimatul 'ursy di rumah gadang dilakukan untuk kemaslahatan yang dipandang baik ditengah-tengah masyarakat. Dengan cara bergotong royong untuk membantu masyarakat yang akan melakukan pesta pernikahan. Oleh karena itu, tradisi walimatul 'ursy di rumah gadang sebagai tempat pesta pernikahan di Nagari Abai kecamatan Sangir Batang Hari kabupaten Solok Selatan tergolong kepada Maslahah Mursalah.

Maslahah Mursalah adalah apa yang dipandang baik oleh akal, sejalan dengan tujuan syara' dalam menetapkan hukum, namun tidak ada pula petunjuk syara' yang memperhitungkannya dan tidak ada pula petunjuk syara' yang menolaknya. Karena pelaksanaan tradisi walimatul 'ursy di rumah gadang, agama Islam tidak ada melarangnya dan tidak pula menghalalkannya.

Selain itu tradisi Nagari Abai kecamatan Sangir Batang Hari kabupaten Solok Selatan menurut analisa penulis termasuk Maslahah yang berarti perbuatan-perbuatan yang mendorong kebaikan manusia. Dalam arti secara umum adalah setiap segala sesuatu yang bermanfaat bagi manusia, baik dalam arti menarik atau menghasilkan keuntungan atau kesenangan atau dalam arti menolak atau menghindarkan seperti menolak kemudharatan atau kerusakan. Jadi setiap yang mengandung dua sisi yaitu menarik atau mendatangkan kemudharatan dan menolak atau menghindarkan kemudharatan (Syarifuddin, 2009: 345).

Berdasarkan penjelasan dari tradisi walimatul 'ursy dalam walimah ini merupakan tradisi yang boleh dilakukan karena begitu banyak kemaslahatan yang terdapat di dalamnya sehingga tidak terdapat bertentangan hukum syara', karena tidak semua perbuatan yang dilakukan oleh manusia harus dijelaskan oleh Nash (Al-Qur'an dan Sunnah).

$$
\text { الاصل في الأشياء الإباحة حتئ يدل الليل عل التحريم }
$$

"Pada dasarnya apapun dibolehkan kecuali ada dalil yang mengharamkannya".

Mengenai pelaksanaan tradisi walimatul 'ursy di rumah gadang di Nagari Abai kecamatan Sangir Batang Hari kabupaten Solok Selatan menurut analisis penulis, disamping termasuk kepada maslahah, juga mengandung unsur positif dari tradisi tersebut adalah masyarakat di Nagari Abai kecamatan Sangir Batang Hari kabupaten Solok Selatan akan berpandangan yang baik kepada pasangan yang menikah, pasangan akan mendapatkan ketenangan batin karena sudah melaksanakan perintah dari nenek moyang dahulu, membangun silahturahmi dengan baik kepada masyarakat di Nagari Abai, dapat memberi tahu kepada masyarakat Nagari Abai, bahwa pasangan tersebut masih gadis dapat diketahui melalui baralek di rumah gadang.

Pelaksanaan walimatul 'ursy di rumah gadang yang ada di Nagari Abai kecamatan Sangir Batang Hari kabupaten Solok Selatan merupakan adat kebiasaan yang dilakukan masyarakat secara berulang-ulang dan terus-menerus hingga sekarang ini. Kaidah hukum islam yang berkaitan dengan adat dan kebiasaan ini adalah: 


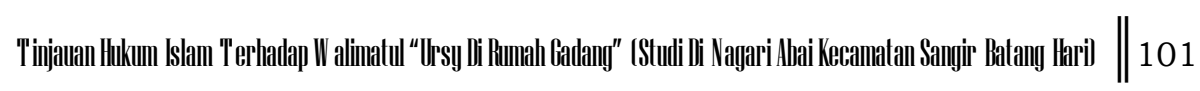

Menurut Abu Zahrah menyatakan 'urf adalah kebiasaan manusia dalam urusan muamalat dan menegakkan urusan-urusan mereka. Ibnu Qayyim al-Jauziyah berpendapat bahwa itu hukum (تغري الحكام بتغري الزمنة) menyatakan berubah karena ada perubahan waktu dan tempat).

Thayyib Khudari al-Sayyid, guru besar Ushul Fiqh Universitas Al-Azhar Kairo, menyatakan bahwa pada prinsipnya mazhab yang empat sepakat menerima adat istiadat sebagai landasan pembentukan hukum (lim fahimah, 2018: 11-14)

آلْعَادَةُ مُحْكَمُ

(Al-'Adatu Muhakkamatun). "Adat kebiasaan itu bisa menjadi landasan hukum". (Suparman Usman, 2001: 69).

Islam dalam berbagai ajaran yang ada didalamnya, menganggap 'adah sebagai partner dan elemen yang bisa diadopsi secara selektif dan proposional, sehingga bisa dijadikan sebagai salah satu penunjang hukum-hukum syara', bukan sebagai landasan yuridis yang berdiri sendiri dan akan melahirkan produk hukum baru, akan tetapi ia hanya sebagai suatu ornamen untuk melegitimasi hukum-hukum syara', sesuai dengan perspektifnya yang tidak bertentangan dengan dengan nash-nash syara'. Jika ditemukan adanya syari'ah yang hanya memberikan ketentuan secara umum, maka batasan pastinya diserahkan kepada penilaian 'adah yang berlaku. Kaidah lain yang obyek pembahasannya terfokus hanya pada kasus-kasus 'adah yaitu kaidah 'urf sebagai berikut. (Dahlan Tamrin, 2010: 204).

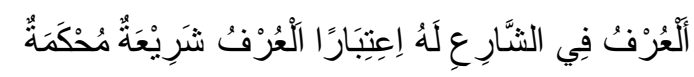

Artinya : 'Urf menurut syara' memiliki suatu penghargaan (bernilai hujjah) dan kaidah 'urf merupakan dasar hukum yang telah dikokohkan.

'Urf adalah keadaan yang sudah tetap dalam diri manusia, dibenarkan oleh akal dan diterima pula oleh tabiat yang sehat. Definisi ini menjelaskan bahwa perkataan dan perbuatan yang jarang dilakukan dan belum dibiasakan oleh sekelompok manusia, tidak dapat disebut sebagai 'urf. (Sunan Autad Sarjana dan Imam Kamaluddin Suratman, 2017: 282). Berdasarkan kaidah fiqh diatas dapat penulis analisa bahwa suatu kejadian yang terjadi secara berulang-ulang yang dilakukan secara terus menerus dan sudah ditetapkan yuridisnya oleh masyarakat atas dasar keputusan orang-orang terdahulu. Maka adat tersebut bersifat mengikat bagi masyarakat setempat.

Jadi menurut analisa penulis tradisi walitul ursy di rumah gadang tersebut adalah adat yang harus di pertahankan oleh masyarakat karena Walimatul 'ursy di rumah gadang merupakan simbol untuk memberitahukan kepada masyarakat bahwa kedua mempelai telah melaksanakan walimatul 'ursy di rumah gadang, walimatul 'ursy di rumah gadang merupakan makna yang berarti bagi kedua mampelai karena masyarakat akan berpandangan baik kepada kedua mempelai dan kedua keluarga mempelai, memperkenalkan kepada Datuak yang empat belas bahwa pernikahan telah berlangsung sesuai dengan adat yang telah ada sejak nenek moyang dahulu, supaya menghindarkan fitnah dan ejekan masyarakat terhadap seseorang yang tidak melakukan walimatul ursy di rumah gadang, supaya mempertahankan agar masyarakat tidak dikucilkan dari pelaksanaan adat di Nagari Abai kecamatan Sangir Batang Hari kabupaten Solok Selatan. 
102

Berdasarkan penjelasan di atas maka dalam pandangan hukum Islam pelaksanaan tradisi walimatul 'ursy di rumah gadang ini adalah dapat dikategorikan kepada 'Urf shahih. 'Urf Shahih adalah suatu kebiasaan yang telah dikenal secara baik dalam masyarakat dan kebiasaan itu sejalan dengan nilai-nilai yang terdapat dalam ajaran islam serta kebiasaan itu tidak menghalalkan yang haram atau sebaliknya (Firdaus, 2017: 109).

Jadi dapat penulis simpulkan bahwasanya pelaksanaan tradisi Walimatul 'ursy di rumah gadang di Nagari Abai kecamatan Sangir Batang Hari kabupaten Solok Selatan. Apabila tidak dilaksanakan maka akan menimbulkan anggapan negatif dari masyarakat, yang mana anggapan masyarakat tersebut berujung kepada sebuah kemudharatan. (Suparman Usman, 2001: 70).

$$
\text { ） الضَّرَرُ يُزَالْ (Al-Dharraru Yuzalu). }
$$

"Kemudaratan, kesulitan, kesempitan atau bahaya harus dihilangkan." Dari kaidah tersebut jelaslah bahwa seluruh bentuk kemudharatan harusdihilangkan, dan menolak kemudharatan lebih diutamakan dari pada mengambil kemaslahatan. Menghilangkan kemudharatan, bagaimanapun bentuknya merupakan tujuan syara' yang wajib dilakukan. Hukum Islam menolak kerusakan atau kemudharatan itu lebih utama daripada mengambil sebuah kemaslahatan, seperti yang tertera dalam kaidah fiqh

$$
\text { درء المفاسد مقدم عل جلب المصالع }
$$

“menolak kerusakan diutamakan ketimbang mengambil kemaslahatan".

Kaidah ini menjelaskan bahwa apabila dalam suatu perbuatan terdapat manfaat atau maslahat dan kemafsadatan (kerusakan) sekaligus, maka yang didahulukan adalah menghilangkan mafsadatnya. Hal ini disababkan suatu kemafsadatan dapat mengakibatkan kemafsadatan atau kerusakan yang lebih besar. (Sugianto, 2014: 9). Kaidah ini menjadi dasar hukum untuk mengambil kehati-hatian dalam suatu hal. Dalam kaidah ini seseorang dituntut untuk memilih satu diantara dua, yaitu mengambil manfaat dan kerusakan. Bila ada dua hal yang sama-sama memiliki unsur bahaya disini lain juga mengandung manfaat. Maka berdasarkan kaidah ini harus menjauhi bahaya ketimbang mengambil sisi baiknya. (Kasmiddin, 2011: 87).

Jadi dapat penulis simpulkan bahwa melaksanakan tradisi adat walimatul 'ursy di Rumah Gadang bagi kedua mempelai dan kedua keluarga mempelai di Nagari Abai Kecamatan Sangir Batang Hari Kabupaten Solok Selatan boleh dilakukan karena membawa suatu kebaikan hidup dalam masyarakat.

\section{KESIMPULAN}

Prosesi walimatul 'ursy di Rumah Gadang merupakan suatu tradisi yang dilakukan dengan syarat dan ketentuan yang telah berlaku untuk melaksanakannya harus mendapatkan izin dari datuak yang memimpin suku tersebut dan dari Datuak Empat Belas maka walimatul 'ursy di Rumah Gadang dapat dilakukan selama tujuh hari tujuh malam, dan juga untuk menjalin silahturahmi dan menghormati kedua keluarga mempelai, yang mana pelaksanaannya dimulai dari peminangan, rapat atau musyawarah yang dilakukan kedua keluarga, dan prosesi walimatul ‘ursy di rumah gadang. 


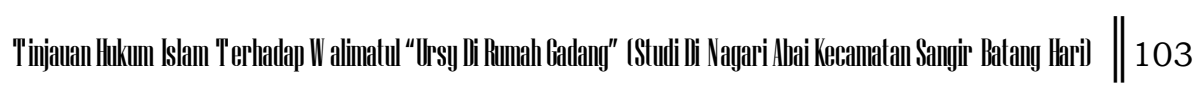

Menurut hukum Islam prosesi walimatul 'ursy di rumah gadang tersebut masuk kepada kategori sesuatu hal yang baik yang merupakan simbol kondisi mempelai dan keluarga mampelai meskipun tidak ada diperintahkan oleh agama dan juga tidak ada larangan untuk melaksanakannya, maka dapat digolongkan kepada maslahah.

\section{DAFTAR PUSTAKA}

Akmal, H. (2019). Konsep Walimah Dalam Pandangan Empat Imam Mazhab. Vol. 16. No. 1. Universitas Darussalam Gontor.

Dahlan. M, (2015). Fikih Munakahat. Yogyakarta: DEEPUBLISH.

Direktorat Pembinaan Peradilan Agama Islam Ditjen Pembinaan Kelembagaan Islam Departemen Agama, (2004).

Efendi, S. (2005). Ushul Fiqh. Kencana: Jakarta.

Endah, H. DT. R. (1991). Adat Istiadat dan Agama di Pedesaan. Universitas Negeri Padang.

Erizal, G. Jurnal Bahasa dan Seni, Kajian Terhadap Landasan Filosofi Pantun Minangkabau Vol 10 No. 1 Tahun 2009.

Fahimah, L. Akomodasi Budaya Lokal (Urf) Dalam Pemahaman Fikih Ulama Mujtahidin. Pascasarjana IAIN Bengkulu.

Firdaus, D.R.S \& Djuara P.Lubis, Djoko Susanto dan Endriatmo Soetarto. (2018). Jurnal Sosiologi Pedesaan, Potret Budaya Masyarakat Minangkabau Berdasarkan Keenam Dimensi Budaya Hofstede. Vol 6 No 2.

Firdaus. (2017). Ushul Figh Metode Mengkaji dan Memahami Hukum Islam Secara Komprehensif. PT Rajagrafindo Persada. Depok.

Jawas, Y.A.Q. (2018). Panduan Keluarga Sakinah. Cetakan Kelimabelas. Pustaka Imam Syafii. Jakarta.

Kasmidin. (2011). Al-qawaed al-fiqhiyyah. Yogyakarta: Lingkar Jaya Yogyakarta.

Kementerian Agama RI. (2014). Al-quranul karim (Mushaf al-Quran dan terjemah). Jakarta: CV. Pustaka Jaya Ilmu.

Peraturan Perundang-undangan. (1990). UU Perkawinan No.1 tahun 1974 dengan Penjelasan PP no.9 tahun 1975. Semarang: Aneka Ilmu.

Peraturan Perundang-undangan. (2001). Inpres Nomor 1 tahun 1991 Kompilasi Hukum Islam. disalin dari "Direktorat Pembinaan Peradilan Agama Islam Ditjen Pembinaan Kelembagaan Islam Departemen Agama.

Putri, S.E. (2020). Sosiologi Hukum. Batusangkar: IAIN Press.

Putri, S.E. (2021). Social Solidarity In Manyaratuih Hari (The 100th Day) Tradition In Taluak Community, Tanah Datar Regency, West Sumatera. International Conference on Humanity, Law and Sharia.

Putri, S.E. (2021). Social Values in Funerary Ceremony Research on Lintau Buo Community, Tanah Datar Regency. Alfuad: Jurnal Sosial Keagamaan, 5(2), 26. https:/ / doi.org/ 10.31958 /jsk.v5i2.4263.

Ramulyo, M. I. (1999). Hukum Perkawinan Islam. Jakarta: Bumi Aksara.

Ramulyo, M.I. (1996). Hukum Perkawinan Islam: Suatu Analisis dari Undang-Undang No. 1 Tahun 1974 dan kompilasi Hukum Islam. Jakarta: Bumi Aksara 
Rofiq, A. (1998). Hukum Perdata Islam di Indonesia. Jakarta: Rajawali.

Sabiq, S. (1983). Figh al-Sunnah Jilid II. Beirut: Dar al-Fikr.

Sabiq, S. (2008). Fikih Sunnah 3. cakrawala publishing. Jakarta.

Shomad, A. (2010). Hukum Islam penormaan Prinsip Syariah dalam Hukum Indonesia. Kencana: Jakarta.

Sucipto. (2015). 'Urf Sebagai Metode Dan Sumber Penemuan Hukum Islam. Vol. 7 No. 1. Dosen Tetap pada Fakultas Syari "eah IAIN Raden Intan Lampung.

Sudirman, R. (1999). Konstruksi Seksualitas Islam dalam Wacana Sosial. Yogyakarta: CV Adipura.

Sudiyat, I. (2007). Hukum Adat, Sketsa Asas. Yogyakarta: Liberty Yogyakarta.

Sugianto. (2014). Human Falah, Membangun Lemma Ekonomi Islam Berbasis Qawâ'id AlFiqhiyah (Studi Kasusالضرريز) Vol 1. No. 1.

Syarifuddin, A. (2006). Hukum Perkawinan Islam di Dunia. Jakarta: Pernada Media.

Tamrin, D. (2010). Kaidah-kaidah Hukum Islam (Kulliyah al-Khamsah). Malang: UIN-Maliki Press.

Usman, S. (2001). Hukum Islam, Asas-asas dan Pengantar Studi Hukum Islam dalam Tata Hukum Indonesia. Jakarta: Gaya Media Pratama.

Yaswirman. (2011). Hukum Keluarga (Karakteristik dan Prospek Doktrin Islam dan Adat dalam Masyarakat Matrilineal Minangkabau). Jakarta: PT. Raja Grafindo Persada.

Zuhaili, W. (2011). Figh Islam wa Adillatuhu. Gema Insani. Jakarta. 